\title{
PHILOSOPHY OF LAW IN FORMING RELIGIOUS-BASED REGIONAL REGULATIONS
}

\author{
Imam Mahdi'; Sirajuddin² \\ 1,2 State Insititute for Islamic Studies (IAIN) Bengkulu \\ Jl. Raden Fatah Kelurahan Pagar Dewa Selebar Bengkulu \\ E-mail: 'imam.mahdi@iainbengkulu.ac.id; ${ }^{2}$ sirajuddin.bkl@gmail.com
}

\begin{abstract}
Philosophy of Law in Forming Religious-Based Regional Regulations. This article aims to reveal and analyze the existence of the philosophy of law in forming a Regional Regulation (Perda) with the goal to become a source of positive laws in Indonesia. The Republic of Indonesia is based on the highest constitution, Pancasila and the 1945 Constitution. Since post-reform provides an opportunity the regional autonomy to write its laws (Perda). The head of the districts and the Regional House of Representatives (DPRD) collaborates to write religious-based regional regulations. Philosophically, each religion has a holy book for its followers, such as the Quran (Islam), the Gospel (Christianity), and the Vedas (Hinduism). Thus, some regions in which dominates by Muslims are intend to propose the Quran as the basis for the formalization of sharia in the Regional Regulation; areas that are predominantly Christian will take the gospel as their basic foundation; and Hindu-majority areas such as Bali will include Vedic teachings in their regional regulations. Consequently, if it does not study philosophically, it likely leads to disunity between inter-religious followers although according to the philosophy of law, the regulation made will be likely spared from the nature of discrimination.
\end{abstract}

Keywords: legal philosophy; religious-based regional regulation; constitution.

\begin{abstract}
Filsafat Hukum dalam pembentukan Peraturan Daerah Bernuansa Agama. Artikel ini ditulis untuk mengungkapkan dan menganalisis keberadaan filsafat hukum dalam membentuk Peraturan Daerah (Perda) sehingga dapat berlaku sebagai sumber hukum positif di Indonesia. Negara Kesatuan Republik Indonesia berlandaskan pada Pancasila dan Undang-Undang Dasar 1945 yang merupakan dasar konstitusi tertinggi. Pascareformasi Lahirlah undang-undang otonomi daerah yang memberikan peluang kepada daerah untuk meproduksi hukum yang disebut peraturan daerah (Perda). Kepala daerah dan Dewan Perwakilan Rakyat Daerah (DPRD) berkolaborasi untuk membentuk Perda bernuansa agama. Secara filosofis, agama memiliki kitab suci sebagai pedoman hidup bagi para pemeluknya, seperti Alquran (Islam), Injil (Kristen), dan Weda (Hindu). Melihat fenomena tersebut, daerah yang mayoritas muslim memiliki kepentingan untuk menjadikan Alquran sebagai landasan formalisasi syariah dalam Perda; daerah yang mayoritas Kristen akan mengambil Injil sebagai dasar perdanya; dan daerah yang mayoritas Hindu seperti Bali akan memasukkan ajaran Weda dalam peraturan daerahnya. Peraturan daerah bernuansa agama jika tidak dikaji secara filsafat akan bersifat diskriminatif dan dapat menimbulkan perpecahan terhadap kerukunan antar umat beragama di Indonesia. Akan tetapi, jika mengacu pada filosofi hukum, maka suatu peraturan yang dibuat akan terhindar dari sifat diskriminasi. Hal ini karena tujuan hukum dalam pandangan filsafat hanyalah bertujuan untuk mencapai keadilan bersama dan kebenaran hakiki.
\end{abstract}

Kata kunci: filsafat hukum; Perda bernuansa agama, konstitusi.

\section{Introduction}

Since the establishment of reformation era, local government creates regional regulation as the highest law products in terms of decentralization implementation. A central government regulation which has become guidance, both in regulation and technical formation, is substituted with regional regulation. This regulation is specifically addressed to empower society to become more creative in terms of prosperity.

Initiatives emerge to escalate both natural and human resources by taking regional regulation as local government foundation, while formalizing the regulation that integrate religious value. Therefore, in terms of philosophical point of view, regional regulation does not merely act an instrument, but 
also should be a universal guidance. Regarding to its existence, regional regulation can be examined into ontological, estimological, and axiological condition. Ontologically, it serves as a positive norm resource; estimologically, the process needs to be noticed; and axiologically, regional regulation should be directed to equity values as well as mutual benefit. ${ }^{1}$

However, in the process of forming regional regulation, local government frequently acts too further and overlooks the guidance of regional regulation formation. For instance, some regulations are revoked or dismissed by the Minister of Home Affairs. Until 2017, the minister has revoked 3,143 regulations, especially regulations proposed by regencies/cities all over Indonesia. These revoked regulations are those which inhibit nation's competitiveness, since they decelerate economic growth, extend bureaucracy process, and detain investment. ${ }^{2}$

Correspond to the aforementioned explanation, there are no religious-based regional regulations found among the revoked regulations. ${ }^{3}$ According to Arskal Salim as quoted in Bush, there are three categorizations of religious-based regulation. First, it is related to public order issue or people morality, such as arrangement on non-gambling, nonprostitution, and non-alcoholic beverage regulation. This issue becomes concern and commitment of all part of community. Second, regulations that relate to religious skills and ritual obligations. The rules of having skill in reading Quran and paying zakah are examples of obligations that a Muslim must have. Third, rules that relate to religious symbols, such as the obligation to wear scarf for women and thawb for men in Friday. This last categorization often provokes discrimination, either in public services by the government or by the community itself. ${ }^{4}$

\footnotetext{
1 Sidharta, Krakteristik Penalaran Hukum Dalam Kontek Indonesia, (Bandung: CV.Utomo, 2006), p. 31.

2 https://setkab.go.id/kemendagri-resmi-umumkan-3-143perda-yang-dibatalkan/, accessed, April 27, 2019.

3 Religious regulations are a general term to refer to local regulations whose material comes from religion, while Sirajuddin M. in his dissertation has noted religious regulations with the term "Regional Regulation on Religion", See. Sirajuddin M., Perda Berbasis Norma Agama, ( Jakarta: PT. rajaGrafindo Persada, 2015), p. 195-213.

${ }^{4}$ Arskal Salim, "Perda Berbasis Agama dan Perlindungan Konstitusional Penegakan HAM”, Jurnal Perempuan No. 60, (Jakarta; Yayasan Jurnal Perempuan, 2008), Print I, p. 111, See also, , accessed, April 27, 2019..
}

Since the verdict of Constitutional Court No. 137/PUU-XIII/2015 was released in April 2017, the authority of Minister of Home Affairs to dismiss regional regulation was withdrawn. The Supreme Court of Indonesia should undertake judicial review over the problematic regional regulations. Many studies on religious-based regional regulations suggest that the process of regulation formation only evokes doubts, which leads to anxiety to discrimination and disregards nation's equity. ${ }^{5}$ Religious-based regulation manifests the lawpolitic of Indonesia that comes from custom law, Islam, and Western law, which all compete in Indonesia's law development ${ }^{6}$. This study aimed to examine profoundly the relationship between law philosophy and religious-based regional regulation formation (law constitution theory) in Indonesia's constitution law system. Consistent with following statement, there are three questions necessarily to be discussed (a) Law philosophy role in regional regulation formation, (b) Values of law philosophy in religious-based regional regulation, and (c) Pro and cons of religious-based regional regulation. This study was based on the assumption that the validity of regulation should have philosophical basis. Once the law-philosophy does not interfere such law products, so that the goals never be achieved.

\section{Legal Philosophy in Religious-Based Regional Regulation's Formation}

One of the reformation targets desired by society is legal reformation. A number of legal breaches occurred in New Order triggers this movement, as the authorities often conducted the following irregularities: (1) law served as a tool to justify over policies and government cases, (2) justice process engineering related to powerful person as well as their families and acquaintances, (3) judicial system was under executive power that tended to comply with power.?

\footnotetext{
${ }^{5}$ Asmuni Mth, "Menimbang Signifikansi Perda Syariat Islam (Sebuah Tinjauan Perspektif Fikih)”, Jurnal: Al-Mawarid Edition XVI Tahun 2006

${ }^{6}$ Nanda Dwi Harya, dkk, "Penerapan Hukum Adat, Hukum Islam, Dan Hukum Barat Dalam Undang-Undang Nomor 21 Tahun 2001 Tentang Otonomi Khusus Papua”, Paper: Fakultas Hukum Universitas Sebelas Maret, 2015.

7 https://www.maxmanroe.com/vid/umum/pengertianreformasi.html, accessed, April 27, 2019
} 
In terms of philosophy, law formation should be universal and not as a tool to justify for particular interest. Philosophy aims at achiving absolute truth. Therefore, the law should adopt both social interests among people and Pancasila ideological, cultural, morality and ethical, spiritual values, as well as equitical values. Gustav Radbruch in his theory of Rechsidee asserted that an ideal law should encompass (1) equity (Grechtmategheit) (2) benefit (Doelmaghteit) and (3) certainty (Rechmategheit). ${ }^{8}$

Pancasila's ideological value in philosopical view as suggested by Notanegoro is as follows ${ }^{9}$

Pancasila ideological value in philosopical view as suggested by Notanegoro is as follows:

1. Belief in one supreme God is a belief on a just and civilized humaninity, on the unity of Indonesia, on democratic rule that is guided by the strength of wisdom resulting from deliberation/representation, and on social justice for all the people of Indonesia.

2. A just and civilized humanity is a humanity which is a belief in the One and Only God, on the unity of Indonesia, on democratic rule that is guided by the strength of wisdom resulting from deliberation/representation, and on social justice for all the people of Indonesia.

3. Unity of Indonesia is a unity which is belief in the One and Only God, on a just and civilized humaninity, on the unity of Indonesia, on democratic rule that is guided by the strength of wisdom resulting from deliberation/ representation, and on social justice for all the people of Indonesia.

4. Democratic rule that is guided by the strength of wisdom resulting from deliberation/ representation is a belief in the One and Only God, on a just and civilized humaninity, on the unity of Indonesia, and on social justice for all the people of Indonesia.

5. Social justice for all the people of Indonesia is a justice which is a belief in the One and Only God, on a just and civilized humaninity,

\footnotetext{
${ }^{8}$ Gustav Radbruch, cited by B. Arief Shidarta, Meuwissen Tentang Pengembanan Hukum, Ilmu Hukum, Teori Hukum dan Filsafat Hukum, (Bandung: PT Refika Aditama, 2007), p. 20-21

${ }_{9}$ Notonagoro, Beberapa Hal Mengenai Falsafah Pantjasila, (Jakarta: Pantjuran Tujuh, 1967), p. 28.
}

on the unity of Indonesia, and on democratic rule that is guided by the strength of wisdom resulting from deliberation/representation.

Pancasila in regulation formation serves as the highest norm and main resource in legal structure. This statement indicates that legal formation should embody Pancasila values as suggested by Notonegoro. As a result, the process of law formation integrates and controls the contrary values of Pancasila ideology.

In terms of state law, Pancasila has distinct characteristics among another state. M. Tahir Azhari suggests the following characteristics:

1. Solid relationship between religion and state

2. Rely on one supreme God

3. Religious liberty in positive manner

4. Atheism and communism restriction

5. Kinship and harmony principle

6. Constitutional system

7. Equality in law

8. Independent jurisdiction. ${ }^{10}$

Moreover, regional regulation formation, as has been stated previously, suggests that since post-reformation, each region has authority to pursue development more creatively in terms of prosperity and peace to citizen based on Pancasila values and philosophy. However, religious-based regulation always causes pros and cons during its process. In fact, this condition will not occur if Pancasila is used as the main legal resource.

Religious-based regional regulation cannot be discriminative to particular religious community. The regulation that obliges Muslim women to dress Islamic clothing (hijab), ${ }^{11}$ as an example is considered having gender bias and unsuitable for civilization values. Nevertheless, this argument is contrary to the human nature which always emphasizes on perfection and morality. Islamic

${ }^{10}$ M. Tahir Azhari, Negara Hukum suatu Studi tentang Prinsipprinsipnya dilihat dari segi Hukum Islam, Implementasinya pada Periode Negara Madinah dan Masa Kini, (Jakarta: Bulan Bintang, 1992), p. 69.

${ }^{11}$ Only one example of a regional regulation which has religious nuances but the there is one that cause pro and cons. Many muslim scholars and human rights activists state that this regulation create or increase discrimination againts women, for instance the regulation that urge muslim women to wear headscarves in public places, See. Indonesia, https:// www.state.gov, accessed, April 30, 2019. 
clothing that covers women's intimate parts is in accordance to religious law. However, this remains figh debatable. Local government should have specific objective ${ }^{12}$ to maintain people morality. It is compulsory to regulate hijab issue since this argument varies by society's way of life as well as consciousness to implement God's command. According to Nur Rohim Yunus, this phenomenon raises pros and conts. The pro party argues that Islamic law is necessarily be implemented due to most Indonesians are Muslim. They also assert that Muslim should return to the Quran and Sunna so that the existing political-social disputes could be overcome..$^{13}$

The Indonesia's Minister of Home Affairs clarifies that regional Islamic law should never existed. The regulations, which are inspired by Islamic sharia, are merely promulgated general rules to overcome social problems, such as alcohol consumption and prostitution. Regarding to regulation in Aceh, the Minister states that the debated regulation is only effective for Muslim that requires them to live daily along with Islamic teachings. ${ }^{14}$ Data from the Ministry of Home Affair show that there are no religious-based regional regulations out of 3,143 revoked regulations from 42,000 province, regency, and city regulations. ${ }^{15}$ In other words, Sirajuddin $M$. asserts that every citizen must believe in one supreme God. Consequently, nation's life should be egalitarian, in which everyone has same rights and status to God, specifically rights and position in law and government. ${ }^{16}$

The regional regulation that obligates Muslim women to wear Islamic clothing is one of legalized moral teachings. In the case of law, it is found that law and morality are inseparable. Natural law theory becomes a meeting point between both. Moreover, either law or morality, both are existed in society in order to manage behavior

${ }^{12}$ The principle of directness, means that every legislation must have clear objectives; See: Provisions of Article 5 of Law of Republic of Indonesia Concerning Making Rules.

${ }^{13}$ Nur Rohim Yunus, "Penerapan Syariat Islam terhadap Peraturan Daerah dalam Sistem Hukum Nasional Indonesia", Jurnal Hunafa: Studia Islamika, Vol 12 No. 2 tahun 2015.

${ }^{14}$ Indonesia, https://www.state.gov. accessed, April 30, 2019.

${ }^{15}$ Daftar Perda/Perkerda dan Peraturan Menteri Dalam Negeri yang Dibatalkan, https://www.kemendagri.go.id, accessed, Mei 8, 2019.

${ }^{16}$ Sirajuddin M, Perda Berbasis ..., p. 187. eventhough with different binding powers. ${ }^{17}$

The religious-based regulations are inclusive to a particular religion. According to Sirajuddin, the characteristic of religious-based regulation relies on its followers, they are targeted to everyone or community. This applied regulation is defined by similar perspective among members in a community which eventually generates legal goals (rechtside). ${ }^{18}$

Moral has a strong relationship with ethics, known as normative theory. Thus, moral that contains norms and values is implemented in behaviour and government's daily activity. Etimologically, norms and values are good if it is implemented properly in society. Ethics correlates with morality. ${ }^{19}$ In philosophy, good and bad things become a main focus in philosophical law.

Government's ethics is a study to behave in a good manner regarding to positive values of human nature. It is also applied ethics in regulating governance. Further, it is a part of practical jurisprudence or law philosophy which manages government affairs in relation to people who manage government agency. ${ }^{20}$

As a country which considers law as a foundation of constitution as quoted in 1945 Constitution Act 1 (3) "Indonesia is a law state". As stated by Indonesian Legal Rountable Team, there are five principles and law indicators, one of them is "open and clear regulations along with public indicator in regulation formation, clarity of regulation content, and access to legislation." ${ }^{21}$ Therefore, regulation formation should include:

a. Undertake law and order to achieve public goals and prevent collision among society

b. Strive for the welfare and prosperity of the people

c. Reinforce Indonesia defense and security

d. Uphold justice. This function is employed towards judicial institution in order to enforce

${ }^{17}$ Andre Ata Ujan, Membangun Hukum Membela Keadilan: Filsafat Hukum, (Yogyakarta: PT. Kanisius, 2009), p. 155

${ }^{18}$ Sirajuddin M, Perda Berbasis... p. 203.

${ }^{19}$ Totok Wahyu Abada, "Aksiologi, Antara Etika, Moral dan Estitika”, Jurnal Ilmu Komunikasi, Vol. 4,No, 2, Maret 2016, p. 187204

${ }^{20}$ Ismail Nurdin, Etika Pemerintahan, (Lintang Rasi Aksara: Yogyakarta, 2017), p. 11.

${ }^{21}$ Tim Indonesian Legal Rountable, Indeks Persepsi Negara Hukum Indonesia 2012, (Jakarta: Indonesian Legal Rountable, 2013), p. 8-9. 
discipline. Regarding to this, a state requires legal products which are applicable to society since law is a facility to create discipline as well as provide justice towards society. ${ }^{22}$

According to Larry Alexander and Emily Sherwin, regulation should meet the following criteria: First, it considers the society, so that discipline as well as people needs could be accommodated; Second, in terms of positivism approach, a regulation can be evaluated to be included in upcoming regulation content; Third, is exclusioner reason. According to Joseph Raz, regulation can be understood as a reason to take an action, as a second command without overlook the "first command" in considering morality process; Fourth, is a witness. A possible way to diminish imbalance is by inviting a witness for who undertake legal violence; Fifth, violation is one of reasons of fears of rules fraud. Consequently, it will lead to the quality of the discussion of legal and morality issues. ${ }^{23}$

Philosopical review in regulation formation has been argued by scholars. As quoted by Jalauddin, ${ }^{24}$ Socrates argued that the essence of law (legislation) is a part of justice. Law has a function to provide justice among society. Law addresses the rules of law regarding to life's ideal that is justice. Consistent with Socrates's, Plato proclaimed that law exists because of agreement or contract. The agreement solely remains that humans are social beings; therefore, there is eagerness to live sociable. Nonetheless, law and state purposes are to achieve discipline and safety, indicating that constitution is a manifestation of society's desire. Rosseau began his elaboration by stating that country's goals are to uphold law and ensure freedom of its citizen, defining that freedom within scope of legislation. In this term, society has rights to partake in legislation formation, in which their voice and intention are eventually manifested into constitution. Cicero agreed that the essence of law is reasoning human ratio, in other words Godly ratio. Therefore, law

${ }^{22}$ Parkim Hyang, " Filsafat Hukum dalam Pembentukan Perundang-undangan Pemilu”, https://udayana.academia.edu, accessed, Mei 5, 2019.

${ }_{23}$ Alexander, Larry and Emily Sherwin.. The Rule of The Rules, Morality, Rules, and the Dilemmas of Law, (Duke University Press. Durham and London, 2001), p. 53-61.

24 Jalaluddin, "Hakikat Dan Fungsi Peraturan PerundangUndangan Sebagai Batu Uji Kritis Terhadap Gagasan Pembentukan Perda Yang Baik", http://jurnal.untad.ac.id, accessed, Mei 5, 2019 is a obligation for human to live peacefully as a human being.

Meanwhile, in the system of legislation, as stated in Article 14 of Law No. 12 of 2011, the contents of the Provincial Regulations and City Regulations contain material in the context of implementing regional autonomy and co-administration tasks, as well as accommodating special conditions of the regional and/or further elaboration of higher legislation. Moreover, the Law No. 23 of 2014 concerning Regional Government explains that in implementing Government Affairs that are under the authority of the region, regional heads and Regional House of Representatives should make regulations as the legal basis for the regions in organizing Regional Autonomy in accordance with the conditions and aspirations of the people and identity of the region. Regional regulations made by the regions only apply within the boundaries of the relevant jurisdiction. However, the regional regulations stipulated by the region may not conflict with the provisions of legislation that are of a higher level in accordance with the hierarchy of laws and regulations. In addition, the regional regulation, as part of the system of legislation, may not conflict with the public interest as stipulated in the rules for drafting the regional regulations.

To measure standardization whether the legislations have been formed based on philosophical thought, Sirajuddin et al. stated that

"Philosophical implementation in this principle means that the formation of legislation must not conflict with the ideals of the law (rechtsidee) in the society, which are what the people expect from the law consists of justice, expediency, and order and welfare. Rechtsidee grows in the system of values of the society about good and bad, their views on individual and community relations." 25

It should be noted that the formation of regional regulations only applies to the jurisdiction of the region. While other regions also form the same regional regulations, the characteristics and functions of the regulations are different. In the legal field, this system is called "Local Wet". ${ }^{26}$

${ }^{25}$ Harry Alexander, Panduan Perancangan Perundangundangan di Indonesia, (Jakarta: XSYS Sulusindo, 2004), p. 20.

${ }^{26}$ Jimly Asshiddiqie, Perihal Undang-Undang, (Konstitusi Press, Jakarta, 2006), p. 8, In other terms, regional regulations 
Regional regulations are made by regional governments as authority of autonomous regions that have authority. The authority to form a regional regulation is carried out by the Regional Head and Regional House of Representatives. ${ }^{27}$ Regional regulations are made by the authorities that produce valid legal substances.

Based on the philosophy of law and philosophy of Islamic law, legal products should not be seen only from the formal side, but also their benefits. In Islamic philosophy, there are no differences between legal products made by the State and those that come from religious norms. The principle of Islamic philosophy is the Sunna of the Prophet Muhammad which is reflected in human mind for the benefit of humanity. In other words, the legal philosophy of law is for the salvation and peace of mankind..$^{28}$

Starting from post-reform, several regions have formed regional regulations that have religious nuances. Those regulations can be categorized into two characters: regulations with inclusive religious nuances and regulations with exclusive religious nuances. ${ }^{29}$ In a review of the legal philosophy, a formed regulation must have benefits for the community besides having values of justice. The values of Pancasila must be implemented in the regulations. Pancasila is still widely used by the community because they feel that it provides benefits for both individuals and society..$^{30}$ On the other hand, this is a good thing in maintaining the relationship between

are called black's law dictionary, it is also called local law, local act or local statute which are described as "a statute that relates to or operates in a particular locality rather than the entire state. (See. 2oBryan A.Garner (ed.),Black's Law dictionary, ST.Paul, Minn, West Group, 1999, p. 950.

27 Ni'matul Huda, Problematika Pembatalan Peraturan Daerah, (Yogyakarta: UII Press, 2010) p. 86, See also, Imam Mahdi, Hukum Tata Negara Indonesia, (Yogyakarta: Teras, 2011), p. 182-186

${ }^{28}$ Musa Asy'ari, Filsafat Islam: Sunah Nabi dalam Berfikir, (Yogyakarta: LESFI, 2002), p. 6.

29 Sirajudin M, Perda Berbasis...p. 195, In the context of religion, Inclusiveness refers to the adherents of a social system that emphasizes the need for individuals to be controlled by a set of beliefs and values. While exclusiveness put emphasizes on the notion of religion as a configuration that represent a realm of holiness ( in the form of social history and socio cultural).See. Nurcholis Majid, Agama Inklusif dan Eksklusif, http://nurcholishmadjid.org, accessed, Mei 5, 2019.

30 Rangga Prabawa Raharja Kartasasmita, Analisis Pembentukan Peraturan Perundang-Undangan Berdasarkan Nilai-Nilai Pancasila Dikaitkan dengan Buku Philosophy of Law dar Mark Tebbi, https://www.academia.edu, accessed, Mei 9, 2019. religion and the state to respect inter-identity in a process of forming the law. ${ }^{31}$ Therefore, the regional regulation is considered to have philosophical value if it has philosophical norm justification. ${ }^{32}$

\section{Regional Regulations with Inclusive Religion Nuances \\ a. Regional regulations of prohibiting alcoholic beverages}

One of the regions that has formed this kind of regulation is a city named Pamekasan, with Regional Regulations No. 18 of 2001 concerning the prohibition of alcoholic beverages. The considerations of formation of the regulation are because alcohol can do harm to health, affect mental attitudes, conflict religious and moral norms, threaten the future generations and public peace. With the issuance of the regulations, the regional government of Pamekasan has successfully preserved the values that exist in the community. This is because the majority of the society in Pamekasan are Muslim, while alcoholic beverages are prohibited in the Quran and can also do harm to health. In addition, the regional regulations of alcohol prohibition are also formed by other regions, for example (i) Regional Regulation No. 5 of 2006 of Malang, (ii) Regional Regulation No. 5 of 2006 of Manokwari, (iii) Regional Regulation No.4 of 2014 of Makassar.

The regional regulations of prohibition of selling and drinking alcohol is actually implemeted in several regulations of Ministry of Trade, which are: (i) Regulation of Ministry of Trade No. 45/M-DAG/PER/12/2010, (ii) in conjuction with Regulation of Ministry of Trade No. 20/M-DAG/ $\mathrm{PER} / 7 / 2011$, (iii) in conjuction with Regulation of Ministry of Trade No. 11/M-DAG/PER/3/2012, (iv) in conjuction with Regulation of Ministry of Trade No.53/M-DAG/PER/12/2012 concerning provisions on the procurement, distribution, sale, supervision and control of alcoholic beverages. Also, Regulation of Ministry of Trade No.

${ }^{31}$ Ifitri, "Whose Authority? Contesting and Negotiating the Idea of a Legitimate Interpretation of Islamic Law in Indonesia," Asian Journal of Comparative Law 10, No. 2, December 2015. p. 193.

${ }^{32}$ Syamsul Bachrie, "Keberadaan Peraturan Daerah dan Permasalahannya”, Jurnal Clavia Fakultas Hukum Universitas 45 Makasar, p. 218-219 
15/M-DAG/PER/ 3/200 concerning supervision and control of imports, distribution and sale, and licensing of alcoholic beverages.

It can be seen from the philosophy of law of the regional regulations about alcoholic beverages that they may threaten the future life of younger generation, trigger disturbances in security and public order, as well as one of factors in the occurrence of violence and criminal acts.

\section{b. Regional Regulations and Religious Norms on Gambling}

Some regions have established regulations on gambling prohibitions such as Qanun of Nangroe Aceh Darussalam Province with regulation No. 13 of 2003 concerning gambling. The purpose of this regulation is to prohibit citizens from carrying out or becoming organizers of gambling, or protecting gamblers. The regulation actually complements the existing regulations.

The regulations of gambling are contradictory in society. On the one hand, Act No. 7 of 1974 in conjuction with Article 303 of the Criminal Code states that people who organize gambling can be given permission by the authorities, but on the other hand, it contradicts with its rules of implementation, which is Act No. 9 of 1981 that prohibits all form of gambling. In theory, the Act by itself is null and void because it is contrary to the regulations above. The discourse to relocate gambling activities such as in Malaysia and Singapore still contradicts to moral, religious and public order values. Gambling will have a negative impact especially for local residents. Since gambling may have negative impacts for local residents, the function of this regulation in the view of legal philosophy is essential, which is to maintain security and justice in the community.

The mandate of legal philosophy written in the establishment of this regional regulation can be observed as in the editorial of the regional regulation which reads "that in essence, gambling is a crime that is contrary to law, religion and morality". From the decision dictum above, it is clear that gambling has the potential to disrupt the peace of the community and can cause social problems.

\section{c. Regional Regulation on Prohibiting Prostitution}

The local regulation on prostitution must be made because it can affect the life order of the community. This is an attempt to change the mental attitude that affects the community. However, the implementation of regulation on prostitution is less than fair. The punishment is only imposed on certain parties, while the perpetrators cannot be charged. The pimps are arrested and will be subject to Article 296 of the Criminal Code in conjunction with Article 506 of the Criminal Code concerning pimps with the prison sentence of 1 year 4 months. But then, how about the punishment for customers and commercial sex workers? Until now, there are no articles in the Criminal Code that regulate criminal law for customers and commercial sex workers. ${ }^{33}$ Therefore, the legal regulations in the form of local regulations are very much needed for regions that want their area to be free from prostitution.

\section{Regional Regulations with Exclusive Religious Nuances}

Regional regulations with exclusive characters have many pros and cons. This is understandable because the regulations are aimed to people with certain religions. Therefore, the regulations are rejected by groups of people who do not agree with religious-based regulations because they cannot be applied universally for the community.

Actually, the arguments put forward by the counter party are inconsistent. Some legal products in the form of laws that have been specifically established for certain religions (Islam) such as the law on pilgrimage, waqf, banking, marriage and zakah philosophycally have benefits and do not contradict with the philosophy of Pancasila. The enacment of Islamic law are actually have been established since colonial era. Mhd. Nur Husen Daulay said that

"...the application of Islamic law is not a new thing in Indonesia. The law has been applied since the Dutch colonial even though it was limited to the law of worship and civil law. It means that it was limited to certain aspects,

33 Sherly Puspita, judul "Bisakah Pelanggan Prostitusi Dijerat Hukum? ,https://megapolitan.kompas.com, accessed Mei 6, 2019. 
but basically there has been recognition of the existence of Islamic law in the community of Indonesia." 34

Some of regional regulations that have exclusive characteristics are as follows:

\section{a. Regional Regulations on Wearing Islamic Clothing}

Province that has the most regulations on wearing Islamic clothing for women are the Province of West Sumatra. There are 19 cities that have formed regulations on how a Muslim should dress their self. One of example is regional regulation of Sawahlunto No. 3 of 2003 on wearing Islamic clothing. As mentioned in Article 3, the purpose of this regulation is to adjust oneself to wear Islamic clothing in their everyday life. This regulation also aims to create Muslim communities who love their culture, namely the Minangkabau culture, that preserves traditional functions that have taken root in the community in accordance with the saying "syara 'mangatao adat mamakai". 35

\section{b. Regional Regulations on Reading Quran and Writing in Arabic}

One of regional regulations that implement reading Quran and writing in Arabic is from the city of Lima Puluh Kota, namely regulation No. 6 of 2003 concerning the obligation to be able to read Quran and write in Arabic for students and people who will get married. The purpose of this regulation is stated in Article 4, which is as means in instilling Faith in Allah to the community in order to form sakinah, mawaddah, warahmah family. ${ }^{36}$

The regulation also applies in Central Bengkulu. Regional Regulation No. 6 of 2016 contains the obligation to be able to read Quran and write in Arabic for students and people who will get married. It is stated in Article 2 that the establishment of this regulation to form a Muslim who reflects the good qualities of human being as mentioned in the

34 Mhd. Nur Husen Daulay, “Efektifitas Penerapan Peraturan Daerah Busana Muslim Muslimah Dalam Mendorong Pelaksanaan Ajaran Islam: Studi Kasus Di Sekolah Menengah Atas Negeri 5 Di Kota Padangsidimpuan", AT-TAFAHUM: Journal of Islamic Law, Vol. 1 No. 1 Januari-Juni 2017. See also, Bustanul Arifin, Perkembangan Hukum Islam di Indonesia Akar Sejarah dan Prospeknya, (Jakarta: Gema Insani Press, 1996), p. 33-34

${ }^{35}$ Sirajuddin M, Perda Berbasis..., p. 204.

${ }^{36}$ Sirajuddin M, Perda Berbasis..., p. 208.
Quran. This is in accordance with the provisions stipulated in Law No. 20 of 2003 concerning the National Education System which states that education is a conscious and planned effort to create a learning atmosphere and learning process so that students actively develop their potential to have religious spiritual strength, self-control, personality, intelligence, noble character, and skills beneficial for himself, society, and country.

\section{c. Regional Regulation on Zakah}

Management of zakah has been regulated by the state since the issuance of Law No. 38 of 1999 concerning the management of zakah, and then amended by Law No. 23 of 2011 concerning the management of zakah. The philosophical review as contained in the consideration of letter $\mathrm{C}$ that zakah is a religious activity that aims to improve justice and welfare of the people. Then, regional regulations on management of zakah were established in several regions because it is stated in the Acts of Article 31 and 32 that in carrying out their duties, provincial and regional BAZNAS (Badan Amil Zakat Nasional or National Zakat Organizer) by the Regional Expenditure Budget and Amil Rights. Therefore, after the issuance of the zakah management law, the regional government is obliged to carry out the zakah management.

The regulations on zakah are made to describe the duties and roles of the governor/regent/mayor in guiding and supervising BAZNAS with the authority under the Law. In addition, with the existence of zakah regulations, the government can directly coordinate the collection of zakah from civil servants and regional-owned enterprises. In certain areas, such as Province of Bengkulu, which is classified as a poor area, zakah from the government has the potential to prosper the community.

\section{d. Regional Regulations about Bible}

Regional regulations about Bible in Manokwari aim to give written recognition to Manokwari as a historic Christian city in Papua. The regulation requires all members of any religion in Manokwari not to be active during worship services on Sunday for Christians in accordance with the Joint of Ministerial Decree of 2006.37

\footnotetext{
37 Perda Injil Manokwari, Antara Sejarah Kekristenan Dan
} 
In a philosophical, sociological and legal view, Benjamin said that the renewal occurred along with the entry of the Gospel, and also accelerated also with the development of human civilization in all fields, turned out to be a challenge for the gospel. These reforms have actually resulted in the ethics, moral and spiritual deterioration of the Papuan people, which has an impact on various actions that conflict with community norms and humanitarian principles. ${ }^{38}$

\section{e. Regional Regulations about "Day of Silence" in Bali}

The regional regulation No. 3 of 2003 is established in the Province of Bali in order to carry out the celebration of Day of Silence by Hindus people in Bali. The regulation prohibits all people who live in Bali to turn on electricity and fire, play music out loud, go out of their house, turn on the internet and do broadcast in mass media. Airports in Bali are also closed in the day and hundreds of flight are canceled during the celebration. ${ }^{39}$

This ritual is conducted to set them aside from from all worldly activities which are known by Balinese as Chatur Brata or four prohibitions. These Chatur Brata consists of Amati Geni (prohibition to light a fire), Amati Karya (prohibition to do any activites), Amati Lelanguan (prohibition to entertain oneself), Amati Lelungaan (prohobition to go out). These prohibitions have symolic meaning to hold back anger. ${ }^{40}$

In the study of philosophy, self-control is the ethics of behaving, while the law is basically to make people do what is good for themselves and others.

\section{Conclusion}

The legal philosophy in the formation of laws is a guiding principle so that legal products have values of expediency, order and justice for society. Therefore, religious-based regional regulations must meet the criteria for the study of legal philosophy. For the Indonesian

\footnotetext{
'Nuansa Intoleransi, https://www.bbc.com, accessed Mei 9, 2019.

${ }^{38}$ Benyamin Malmambessy, Tinjauan Kritis Terhadap Raperda Manokwari "Kota Injil" https://media.neliti.com.

39 https://id.wikipedia.org, accessed Mei 9, 2019.

${ }^{40}$ Dede Sholahuddin, Toleransi, Ala Kongkrit di Bali, https://news.detik.com
}

people, Pancasila is the main reference. The religious-based regional regulations, both with an inclusive character and exclusive character in their formation, have met juridical and technical requirements. This can be proven that none of the religious-based regulations were revoked by the government.

The pros and cons of the emergence of religious-based regional regulations are natural in Indonesia whch is a democratic and diverse country. Religious regulations in Indonesia were formed to raise awareness for the community to better understand the laws adopted by religious followers in order to achieve a more orderly life.

\section{References}

Abada, Totok Wahyu, "Aksiologi, Antara Etika, Moral dan Estitika", Jurnal Ilmu Komunikasi, Vol 4, No. 2, Maret 2016.

Alaluddin, "Hakikat Dan Fungsi Peraturan PerundangUndangan Sebagai Batu Uji Kritis Terhadap Gagasan Pembentukan Perda Yang Baik" http:// jurnal.untad.ac.id, accessed tanggal 5 Mei 2019

Alexander, Harry, Panduan Perancangan Perundangundangan di Indonesia, Jakarta: XSYS Sulusindo, 2004.

Alexander, Larry and Emily Sherwin, The Rule of The Rules, Morality, Rules, and the Dilemmas of Law, Duke University Press. Durham and London, 2001.

Alfitri, "Whose Authority? Contesting and Negotiating the Idea of a Legitimate Interpretation of Islamic Law in Indonesia," Asian Journal of Comparative Law 10, No. 2 December 2015.

Arifin, Bustanul, 1996, Perkembangan Hukum Islam di Indonesia Akar Sejarah dan Prospeknya, Jakarta: Gema Insani Press.

Asmuni Mth, "Menimbang Signifikansi Perda Syariat Islam, (Sebuah Tinjauan Perspektif Fikih)", Jurnal: Al-Mawarid Edisi XVI Tahun 2006.

Asshiddiqie, Jimly, Perihal Undang-Undang, Jakarta: Konstitusi Press, 2006.

Asy'ari, Musa, Filsafat Islam: Sunah Nabi dalam Berfikir, Yogyakarta: LESFI, , 2002.

Azhari, M. Tahir, Negara Hukum suatu Studi tentang Prinsip-prinsipnya dilihat dari segi Hukum Islam, Implementasinya pada Periode Negara Madinah dan Masa Kini, Jakarta: Bulan Bintang, 1992.

Bachrie, Syamsul, "Keberadaan Peraturan Daerah 
dan Permasalahannya", Jurnal Clavia Fakultas Hukum Universitas 45 Makasar.

Bryan A.Garner (ed.), Black's Law dictionary, ST.Paul, Minn, West Group, 1999.

Daftar Perda/Perkerda dan Peraturan Menteri Dalam Negeri yang Dibatalkan, https://www. kemendagri.go.id, accessed, Mei 8, 2019.

Daulay, Mhd. Nur Husen, Efektifitas Penerapan Peraturan Daerah Busana Muslim Muslimah Dalam Mendorong Pelaksanaan Ajaran Islam: Studi Kasus Di Sekolah Menengah Atas Negeri Hamami, Abbas, dalam Tim Dosen Filsafat IImu Fak. Filsafat UGM, Filsafat IImu, Yogyakarta: Liberty, 1996.

Hamidi, Jazim, "Makna dan Kedudukan Hukum Naskah Proklamasi 17 Agustus 1945 Dalam Sistem Ketatanegaraan Republik Indonesia", Disertasi on Pascasarjana Program, Universitas Padjadjaran, Bandung, 2005.

Harya, Nanda Dwi, dkk, "Penerapan Hukum Adat, Hukum Islam, Dan Hukum Barat Dalam UndangUndang Nomor 21 Tahun 2001 Tentang Otonomi Khusus Papua", Paper: Fakultas Hukum Universitas Sebelas Maret, 2015.

https://id.wikipedia.org, accessed, Mei 9, 2019. https://setkab.go.id/kemendagri-resmi-umumkan3-143-perda-yang-dibatalkan/ accessed, April 27, 2019.

https://www.maxmanroe.com/vid/umum/pengertianreformasi.html

Huda, Ni'matul, Problematika Pembatalan Peraturan Daerah, Yogyakarta: UII Press, 2010.

Hyang, Parkim, Filsafat Hukum dalam Pembentukan Perundang-undangan Pemilu, https://udayana. academia.edu, accessed, Mei 5, 2019.

Indonesia, https://www.state.gov, accessed, April 30, 2019.

Indonesia, https://www.state.gov, accessed, April 30, 2019.

Indonesia, https://www.state.gov, accessed, April 30, 2019.

Kartasasmita, Rangga Prabawa Raharja, Analisis Pembentukan Peraturan Perundang-Undangan Berdasarkan Nilai-Nilai Pancasila Dikaitkan dengan Buku Philosophy of Law dar Mark Tebbi, https:// www.academia.edu, accessed, Mei 9, 2019.

Lubis, M. Sofyan, "Tinjauan Hukum Tentang Judi” Jurnal. Hukum On Line, accessed Mei 6, 2019 Mahdi, Imam, Hukum Perencanaan Pembangunan Daerah, Yogyakarta: Pustaka Pelajar, 2017.
, “Ilmu Hukum dan Perkembangannya (Kajian Hukum Normatif)", Jurnal: Nuansa, Vol. ix No. 2 Desember 2016.

, Hukum Tata Negara Indonesia, Yogyakarta: Teras, 2011.

Majid, Nurcholis, Agama Inklusif dan Eksklusif, http:// nurcholishmadjid.org, accessed, Mei 5, 2019.

Malmambessy, Benyamin, Tinjauan Kritis Terhadap Raperda Manokwari “Kota Injil” https://media. neliti.com.

Notonagoro, Beberapa Hal Mengenai Falsafah Pantjasila, Jakarta: Pantjuran Tujuh, 1967.

Nurdin, Ismail, Etika Pemerintahan, Yogyakarta: Lintang Rasi Aksara, 2017.

http://wahidfoundation.org, accessed, April 27, 2019. Perda Injil Manokwari, Antara Sejarah Kekristenan Dan 'Nuansa Intoleransi, https://www.bbc.com, accessed, Mei 9, 2019.

Puspita, Rini, “Efektifitas Penerapan Perda Berbusana Muslim danMuslimah dalam Mendorong Ajaran Islam: Studi Kasus di Sekolah Menengah Atas Negeri 5 Padang Sidempuan", AT-TAFAHUM: Journal of Islamic Law, Vol. 1 No. 1 JanuariJuni 2017.

Salim, Arskal, "Perda Berbasis Agama dan Perlindungan Konstitusional Penegakan HAM", Jurnal Perempuan No. 60, Jakarta; Yayasan Jurnal Perempuan, 2008.

Sherly Puspita, judul "Bisakah Pelanggan Prostitusi Dijerat Hukum?" https://megapolitan.kompas. com. accessed, Mei 6, 2019.

Shidarta, B. Arief, Meuwissen Tentang Pengembanan Hukum, Ilmu Hukum, Teori Hukum dan Filsafat Hukum, PT Refika Aditama, Bandung, 2007.

Sholahuddin, Dede, Toleransi, Ala Kongkrit di Bali, https://news.detik.com

Sidharta, B. Arief, Krakteristik Penalaran Hukum Dalam Kontek Indonesia, Bandung: CV.Utomo, Sirajuddin M., Perda Berbasis Norma Agama, Jakarta: PT. RajaGrafindo Persada, 2015.

Tim Indonesian Legal Rountable, Indeks Persepsi Negara Hukum Indonesia 2012, Jakarta: Indonesian Legal Rountable, 2013.

Ujan, Andre Ata, Membangun Hukum Membela Keadilan: Filsafat Hukum, Yogyakarta: PT. Kanisius, 2009.

Yunus, Nur Rohim, "Penerapan Syariat Islam terhadap Peraturan Daerah dalam Sistem Hukum Nasional Indonesia", Jurnal Hunafa: Studia Islamika, Vol 12 No. 2 tahun 2015. 